\title{
POLITIK RAKYAT KAMPUNG DI KOTA SURABAYA \\ AWAL ABAD KE-20
}

\author{
Purnawan Basundoro ${ }^{1}$
}

\begin{abstract}
This article aims to explain the politics activities by the villagers in Surabaya at the early of 20th century. The villagers was always considered as the passive people who refused to be involved in a conflict, therefore didn't do the politic. The historic methodology is taken in this research by referring to the documents from the same century, the newspaper in Surabaya, and also referring to other tertiary resources. The approach chosen is the politic history, a history to describe the struggle of the people to achieve their will. The villagers had various strategy and tactic. As for the villagers who already had the experience of education, even though it was only a basic education, they wrote so many protests in the newspaper related to the decisions of the colonial government which were not in their favour. There was a newspaper in Surabaya managed by the indigenous people at that time, middle scale, and eager to gather all the complaint from the low class society. They also protested directly to the government by using the politic organisation. The formal gathering held by the member of the gemeenteraad, known as "begandring", was used by the villagers to speak up their aspiration.
\end{abstract}

Keywords: Surabaya, politic, and people

\section{Pengantar}

Penghuni kampung perkotaan sering dianggap sebagai orang-orang yang statis dan apolitis, yang tidak mau merespon perubahan secara cepat, dan tidak mau terlibat dalam konflik secara terbuka. Dengan demikian, maka kampung sering diidentikan dengan romantisme tentang suasana yang akrab, guyub antar sesama penghuni, dan saling bergotong-royong dalam mengerjakan sesuatu. Sehingga, dalam studi-studi sosiologi selalu ditarik kesimpulan bahwa warga kampung adalah warga yang bercorak paguyuban. Namun, pada periode tertentu gambaran tersebut hanya cocok untuk mendefinisikan masyarakat kampung di pedesaan. Kajian geografi, sejarah, dan sosiologi ternyata menemukan fakta bahwa di berbagai kota besar di Indonesia keberadaan kampung ternyata eksis, bahkan sampai saat ini.

1 Staf Pengajar Departemen Ilmu Sejarah, Fakultas Ilmu Budaya Universitas Airlangga, Surabaya 
Kampung adalah hunian yang identik dengan pedesaan, dengan penghuni yang masih mempraktekan pola hidup dan budaya desa. ${ }^{2}$

Beberapa kajian politik dan sejarah perkotaan menunjukkan bahwa rakyat yang tinggal di kampung perkotaan ternyata tidak seperti yang dibayangkan sebagian ahli, yang melihat masyarakat kampung sebagai masyarakat yang statis. Di beberapa kota besar rakyat kampung telah terlibat dalam berbagai aktivitas politik, walaupun pada tingkat lokal dengan derajat yang masih rendah. Perlawanan rakyat Indonesia terhadap penjajahan, yang sebagian besar dilakukan oleh masyarakat perkotaan juga melibatkan rakyat kampung yang menunjukkan bahwa mereka bukanlah orang-orang yang apolitis. ${ }^{3}$

Studi tentang keterlibatan politik rakyat kampung perkotaan belum banyak dilakukan, sehingga belum bisa ditarik kesimpulan-kesimpulan umum tentang motivasi yang mendasari gerakan-gerakan politik rakyat kampung. Studi sejarah tentang tema dimaksud bisa menjelaskan lebih jauh tentang motivasi tersebut, karena studi sejarah bisa menelusur lebih jauh dalam konteks waktu yang panjang. ${ }^{4}$

Kota Surabaya merupakan salah satu kota yang memiliki kampung-kampung yang tersebar di banyak lokasi. Keberadaan kampung-kampung tersebut tidak bisa dilepaskan dengan sejarah panjang Kota Surabaya yang diduga awalnya merupakan pedesaan di tepi muara Sungai Brantas. Ketika kawasan Surabaya secara perlahan berubah menjadi perkotaan, hunian penduduk yang disebut kampung tetap bertahan dengan corak pedesaan yang kental, baik dari aspek kultural maupun aspek fisik. Akibatnya, kampung berubah menjadi semacam enclave bagi orangorang yang tetap memegang teguh budaya pedesaan yang bersifat agraris. Kampung-kampung di Kota Surabaya dihuni oleh orang-orang dengan latar belakang sosial dan ekonomi yang amat beragam. Sebagian besar dari mereka adalah penduduk asli Kota Surabaya yang mengidentifikasikan dirinya sebagai pendukung budaya arek. ${ }^{5}$ Di kampung-kampung tersebut juga tinggal tokoh-tokoh politik yang

${ }^{2}$ William H. Frederick, Pandangan dan Gejolak Masyarakat Kota dan Lahirnya Revolusi Indonesia, Surabaya 1926 - 1946 (Jakarta: Gramedia, 1989), hlm. 9

${ }^{3}$ Susan Blackburn, Jakarta: Sejarah 400 Tahun. Jakarta: Masup, 2011; lihat juga; Soemardjan, Perubahan Sosial di Yogyakarta (Jakarta: Komunitas Bambu, 2009).

${ }^{4}$ Kuntowijoyo, Metodologi Sejarah, (Yogyakarta: Tiara Wacana, 2003)

${ }^{5}$ Purnawan Basundoro, Pengantar Sejarah Kota, (Yogyakarta: Ombak, 2012) 
mewarnai dinamika poltik di Kota Surabaya. Keberadaan tokoh-tokoh politik tersebut tentu saja akan mewarnai kondisi sosial di perkampungan setempat. ${ }^{6}$

Studi-studi pendahuluan menyebutkan bahwa gerakan-gerakan politik rakyat kampung di Kota Surabaya sudah berlangsung cukup lama dan mengalami akselerasi sejak awal abad ke-20. Gerakan-gerakan politik rakyat kampung tidak bisa dilepaskan dengan eksistensi penjajah Belanda yang bercokol di kota tersebut sejak lama. Berbagai benturan kepentingan yang melibatkan kedua belah pihak, dan tidak jarang kepentingan-kepentingan tersebut mengharuskan mereka saling berhadapan, mengakibatkan mereka mencari jalan keluar sendiri-sendiri yang mengerucut dalam tindakan-tindakan politik. Tindakan tersebut tentu saja bermotivasi untuk mengalahkan pihak lawan.

Pada awal abad ke-20, pemerintah kolonial Belanda membentuk pemerintahan otonom di Kota Surabaya sebagai dampak Undang-Undang Desentralisasi Tahun 1903 (Desentralisatie Wet 1903). Pembentukan pemerintah kota yang otonom membawa konsekuensi dilibatkannya seluruh elemen masyarakat kota untuk membiayai roda pemerintahan. Hal tersebut telah menuai protes yang luar biasa dari rakyat perkampungan di Kota Surabaya dan berubah menjadi gerakangerakan politik.7 Gerakan-gerakan politik semacam itu merupakan sedikit contoh dari kegiatan politik rakyat kampung di Kota Surabaya.

Artikel ini mengungkap secara lebih jauh kegiatan-kegiatan politik rakyat kampung di Kota Surabaya sejak awal abad ke-20 sampai tahun 1960. Aktivitas politik rakyat kampung Kota Surabaya tentu saja terkait erat dengan karakter kultural masyarakat setempat yang sering disebut sebagai budaya arek. Budaya arek telah menjadi identitas pembeda atas masyarakat Kota Surabaya terhadap masyarakat lain. Orang-orang dengan budaya arek dianggap sebagai pribadi yang mandiri dan pemberani. ${ }^{8}$

\section{Kampung di Kota Surabaya Awal Abad ke-20}

Kampung atau perkampungan di perkotaan sering diartikan sebagai pemukiman khas yang mengacu pada hal serupa yang ada di pedesaan. Hans Dieter Evers misalnya, menggambarkan kampung sebagai sesuatu yang terkait dengan

\footnotetext{
${ }^{6}$ Robbie Peters, Surabaya, 1945-2010; Neighbourhood, State, and Economy in Indonesia's City of Struggle, (Singapore: NUS Press, 2013).

${ }^{7}$ Purnawan Basundoro, Merebut Ruang Kota: Aksi Rakyat Miskin Kota Surabaya 1900-1960an (Jakarta: Marjin Kiri, 2013)

${ }^{8}$ Purnawan Basundoro, op.cit., 2012
} 
"desa" dan komunitas-komunitas, sehingga kampung bukanlah gambaran fisik belaka namun lebih mengacu pada penghuninya (komunitas). ${ }^{9}$ Penghuni kampung digambarkan oleh Sulivan sebagai kebertetanggaan yang baik (neighbourliness), yaitu suasana kekeluargaan, kebersamaan, keharmonisan, suatu situasi di mana orang hidup damai dan kompak, yang biasa dilukiskan dengan kata "rukun". ${ }^{10}$ Dalam teori-teori sosial, komunitas yang ditandai dengan sifat kekeluargaan yang erat dan harmonis identik dengan masyarakat pedesaan. Jika kondisi tersebut masih tersisa pada komunitas-komunitas di perkotaan atau di kampung kota, maka bisa diduga bahwa kampung-kampung di perkotaan merupakan kelanjutan dari komunitas pedesaan.

Surabaya merupakan salah satu kota di Jawa yang pada awal abad ke-20, secara bersamaan sudah memperlihatkan ciri metropolis dan juga masih mencerminkan situasi agraris. Sebagian masyarakat, terutama masyarakat Eropa sudah tinggal di pemukiman-pemukiman elit di real estatet, namun sebagian besar, terutama masyarakat Bumiputra, masih tinggal di pemukiman-pemukiman khas pedesaan Jawa. Mereka tinggal di kampung-kampung dengan kondisi sederhana, rumah-rumah terbangun dari bahan-bahan apa adanya yang ditemukan di sekeliling mereka, jalanan masih berupa jalan tanah yang sempit dan becek pada musim hujan, kebutuhan air masih bergantung pada air sungai atau sumur, serta kondisi lain yang sangat jauh dari layak.

Berdasarkan sensus penduduk yang dilaksanakan pada tahun 1930, diketahui bahwa 91 persen orang Eropa di Kota Surabaya tinggal di rumah permanen yang terbuat dari batu bata. Sementara masyarakat Bumiputra yang tinggal di rumah dengan bahan yang sama hanya 16 persen. Sebanyak 64 persen masyarakat Bumiputra tinggal di rumah non-permanen, yang terbuat dari bahan-bahan seadanya. ${ }^{11}$ Rumah-rumah milik masyarakat Bumiputra di Kota Surabaya sering kali dituding oleh masyarakat Eropa sebagai sumber penyakit yang sering terjangkit di kota ini. Kondisi rumah-rumah yang dibangun dengan bahan-bahan seadanya dianggap menjadi sarang binatang-binatang yang bisa menyebarkan virus penyakit, seperti tikus yang bisa menyebarkan virus penyakit pes. Pemukiman masyarakat

\footnotetext{
${ }^{9}$ Hans-Dieter Evers dan Rudiger Korff, Urbanisme di Asia Tenggara: Makna dan Kekuasaan dalam Ruang-ruang Sosial, (Jakarta: Yayasan Obor Inonesia, 2002), hlm. 408.

10 J. Sullivan, Local Government and Community in Java: An Urban Case Study, (Singapore: Oxford University Press, 1992), hlm. 106.

11 H.W. Dick, Surabaya City of Work: A Socioeconomic History 1900-2000, (Athens: Ohio University Press, 2002), hlm. 143.
} 
Eropa yang rata-rata dibangun menurut model real estate sangat kontras dengan kondisi pemukiman masyarakat Bumiputra. Menurut Von Faber, sebagian besar rumah-rumah masyarakat Bumiputra yang tinggal di kampung-kampung lebih mirip kandang binatang. ${ }^{12}$

Pemukiman masyarakat Bumiputra berada di kampung-kampung yang tersebar di banyak tempat di Kota Surabaya. Sebagian besar kampung terbentuk dari pemukiman-pemukiman kecil yang berada di antara lahan-lahan pertanian dan tambak-tambak garam. Pemukiman tersebut dari waktu ke waktu mengalami perluasan akibat pertambahan penduduk yang terjadi secara simultan. Pada awal abad ke-20, sebagian perkampungan yang dihuni oleh masyarakat Bumiputra di Kota Surabaya berada di tanah-tanah yang berstatus sebagai tanah partikelir, yaitu tanah yang dikuasai oleh perorangan akibat proses jual beli pada masa awal kekuasaan Belanda di Surabaya, ${ }^{13}$ sebagian lainnya tinggal di perkampungan yang sudah berada di bawah kekuasaan Pemerintah Kota Surabaya. Tanah partikelir adalah kawasan yang berada di luar kontrol otoritas resmi, karena tanah tersebut berada di bawah kekuasaan perorangan. Dengan demikian, maka kondisi pemukiman yang ada di kawasan tersebut juga tidak tersentuh oleh programprogram perbaikan kampung yang diselenggarakan oleh pemerintah.

\section{Lahirnya Kesadaran Berpolitik Rakyat Kampung}

Makna politik bagi rakyat kampung di Kota Surabaya pada masa kolonial, diartikan sebagai suatu taktik dalam menghadapi kekuatan dari luar, terutama penjajah Belanda yang memegang kendali kekuasaan pada waktu itu. Kekuatan dari luar juga bisa diartikan sebagai kelompok masyarakat non-Surabaya, seperti kelompok masyarakat Cina, Arab, Indo, dan lain-lain, yang mereka anggap sebagai kelompok masyarakat yang akan mengusik eksistensi rakyat kampung Kota Surabaya. Dalam menghadapi kelompok-kelompok dari luar, rakyat kampung di Kota Surabaya mengidentifikasikan diri mereka sebagai Arek Suroboyo, yang memiliki karakter dan sifat-sifat berbeda dengan kelompok di luar mereka. Arek Suroboyo mengidentifikasikan diri mereka sebagai warga asli Kota Surabaya, pemilik sah kota tersebut, yang memiliki budaya dan tingkah laku berbeda dengan orang-

\footnotetext{
12 G.H. von Faber, Nieuw Soerabaia: De geschiedenis van Indie's voornaamste koopstad in de eerste kwarteeuw sedert hare instelling 1906-1931, (Soerabaia: N.V. Boekhandel en Drukkerij, 1936)

13 Tentang proses terbentuknya tanah-tanah partikelir di Surabaya bisa dilihat pada Purnawan Basundoro, Dua Kota Tiga Zaman: Surabaya dan Malang sejak Kolonial sampai Kemerdekaan, (Yogyakarta: Ombak, 2009), Bab III.
} 
orang di luar kelompok dan budaya mereka. ${ }^{14}$ Tidak jelas benar, bagaimana budaya arek terbentuk sehingga menumbuhkan karakter yang berbeda bagi para penganutnya.

Kesadaran berpolitik rakyat kampung terbentuk secara perlahan-lahan seiring dengan dinamika yang berkembang di Kota Surabaya. Seringnya kekuatan luar mengekspansi Kota Surabaya, telah membuat kesadaran berpolitik rakyat kota ini tumbuh. Mereka menjadi kekuatan yang sering dikonsolidasikan untuk melawan kekuatan dari luar tersebut. Jika mengacu sejarah berdirinya kota ini yang dikaitkaitkan pengusiran bala tentara Tartar oleh Raden Wijaya pada akhir abad ke-13, maka tidak menutup kemungkinan pada saat itu kesadaran berpolitik untuk melawan kekuatan ekspansionis dari luar telah terbangun pada rakyat kampung di Kota Surabaya. Kesadaran tersebut terus tumbuh dan berkembang ketika kekuasaan Mataram menduduki kawasan tersebut pada abad ke-17 dan disambung dengan kekuasaan kolonial Belanda yang mengiringi dilepaskannya pesisir utara Jawa oleh Mataram kepada Belanda akibat persoalan hutang budi. Akibatnya, sejak pertengahan abad ke-18, Surabaya secara resmi di bawah kekuasaan kolonial Belanda.

Keberadaan Belanda di Kota Surabaya telah menyebabkan ikatan sosial penghuni kota ini tercabik. Lahirnya status baru pada kampung-kampung tempat tinggal warga Bumiputra akibat proses jual beli kawasan oleh para penguasa Belanda telah menyebabkan tumbuh benih-benih perlawanan secara individual dan secara kelompok kepada kekuasaan kolonial. Akibat proses jual-beli kawasan oleh pejabat kolonial, status kampung-kampung di Kota Surabaya terbelah menjadi dua, yaitu kampung partikelir dan kampung non-partikelir. Kampung partikelir lahir dari kawasan yang telah dibeli oleh para pengusaha swasta serta para pejabat kolonial. Selama akhir abad ke-19 sampai awal abad ke-20, di kawasan partikelir telah lahir perlawanan-perlawanan sporadis yang ditujukan kepada pemilik kawasan serta kepada pemerintah kolonial. Penyebab tumbuhnya kesadaran perlawanan tersebut salah satunya adalah kondisi kehidupan keseharian kegiatan-kegiatan kerja paksa yang disponsori oleh pemilik kawasan. ${ }^{15}$

Lahirnya lembaga pendidikan di Kota Surabaya, baik pendidikan yang berbasis keagamaan (pesantren) maupun pendidikan umum yang disponsori oleh

\footnotetext{
${ }^{14}$ Lihat Akhudiat, Masuk Kampung Keluar Kampung: Surabaya Kilas Balik, (Surabaya Henk Publica, 2008), hlm. 115

15 Purnawan Basundoro, Dua Kota Tiga Zaman: Surabaya dan Malang sejak Kolonial sampai Kemerdekaan, (Yogyakarta: Ombak, 2009), Bab III
} 
pemerintah kolonial telah membentuk kesadaran baru bagi warga Kota Surabaya. Pendidikan berbasis keagamaan (Islam) diasuh oleh para pemuka agama, yang sebagian dari mereka mendapat inspirasi dan kesadaran baru setelah menunaikan ibadah haji di tanah suci. Di sana mereka mendapatkan berbagai masukan pengetahuan baru, terutama tentang eksistensi nilai-nilai keislaman. Tidak jarang kesadaran baru yang mereka peroleh di tanah suci membangkitkan bibit-bibit perlawanan terhadap kolonialisme yang dianggap merupakan representasi musuh Islam, yaitu kekafiran. Pemberontakan petani di Gedangan, kawasan perkebunan di selatan Kota Surabaya, yang dipimpin oleh Kyai Hasan Mukmin merupakan contoh pemberontakan yang lahir karena kesadaran keagamaan yang bercampur dengan kesadaran ketertindasan yang dipimpin oleh seorang tokoh agama dalam. Pesantren-pesantren di Kota Surabaya banyak terdapat di kampung-kampung. Inspirasi berdirinya lembaga pendidikan keagamaan tersebut tentu saja tidak bisa dilepaskan dengan tokoh penyebar agama Islam di Kota Surabaya, yaitu Sunan Ampel yang makamnya terdapat di Kampung Ampel. Salah satu pondok pesantren tua di Kota Surabaya adalah Pondok Pesantren Sidoresmo, yang sering disebut sebagai Pondok Pesantren Dresmo yang terletak di kawasan Wonokromo. Di duga pondok pesantren ini lahir tidak terlalu lama sejak periode kewalian Sunan Kalijaga. ${ }^{16}$

Kehadiran lembaga pendidikan modern yang disponsori oleh pemerintah kolonial Belanda telah membuka cakrawala baru bagi sebagian kecil rakyat kampung di Kota Surabaya. Pada awal berdirinya sekolah-sekolah modern di kota ini, rakyat kampung bukanlah subjek dari kegiatan pendidikan modern. Subjek utama dari kegiatan tersebut adalah anak-anak Eropa serta sebagian dari anak-anak para elit Bumiputra. Menurut catatan Von Faber, lembaga pendidikan Barat pertama di Kota Surabaya didirikan pada tahun 1822 yang didirikan oleh C.C. Werner. Lembaga pendidikan tersebut didirikan untuk menampung anak-anak yang orang tuanya tidak mampu memberikan pendidikan kepada mereka di rumah. Sekolah tersebut pada tahun 1845 memiliki murid 35 orang. Tahun 1849 pemerintah kolonial di Surabaya mendirikan lembaga pendidikan resmi kedua berdasarkan keputusan nomor 37 tanggal 2 September 1849. Sekolah tersebut diajar oleh tiga guru pria dan seorang guru wanita. Jumlah murid digambarkan tidak sebanding dengan lebar bangunan yang digunakan untuk sekolah, sehingga murid-murid berdesak-desakan

${ }_{16}$ Lihat Darul Aqsha, K.H. Mas Mansyur (1896-1946): Perjuangan dan Pemikiran, (Jakarta, Erlangga, 2004) 
seperti Ikan Haring di dalam tong. ${ }^{17}$ Sasaran lembaga pendidikan tersebut adalah anak-anak Eropa yang tinggal di Kota Surabaya.

Kesempatan sekolah pada anak-anak Bumiputra di Kota Surabaya baru dibuka pada tahun 1860. Pada tahun itu, pemerintah kolonial melonggarkan kesempatan pada anak-anak Bumiputra memasuki sekolah Barat, namun hanya dikhususkan untuk anak-anak dan kerabat para bangsawan. Mereka dididik di sekolah Barat agar kelak bisa menggantikan orang tua yang menempuh karir sebagai pejabat. ${ }^{18}$ Adapun anak-anak Bumiputra kebanyakan, hanya berkesempatan sekolah di sekolah agama (pesantren) di bawah bimbingan seorang kyai, yang jumlahnya pada waktu itu cukup banyak yaitu 162 buah. Mereka hanya diberi pelajaran membaca Al Qur'an, yang dibacakan dalam bahasa Arab tanpa mereka tahu artinya. Para murid tersebut hanya dipersiapkan sebagai santri dan berusaha menerapkan secara cermat dalam kehidupan sehari-hari. Para murid yang datang dari jauh tinggal di rumah-rumah guru mereka atau di pekarangan.

Keberadaan lembaga pendidikan, baik pendidikan Barat maupun agama, telah memberi kesempatan kepada penduduk Bumiputra menyerap berbagai pengetahuan baru yang belum mereka peroleh sebelumnya. Pada tahap awal, hanya anak-anak Bangsawan dan kerabat yang boleh memasuki sekolah-sekolah umum, namun demikian dari merekalah pengetahuan baru menyebar ke anak-anak Bumiputra yang bukan bangsawan. Penyerapan serba terbatas tersebut biasanya melalui orang-orang tua Bumiputra yang bekerja di rumah-rumah bangsawan sebagai pembantu rumah tangga. Pada perkembangan selanjutnya, pemerintah kolonial atas desakan kaum progresif di negeri Belanda mengeluarkan kebijakan politik etis, yang salah satunya adalah memberi kesempatan membuka sekolahsekolah rendah untuk anak-anak Bumiputra. ${ }^{19}$ Lembaga pendidikan yang didirikan oleh pemerintah kolonial yang diperuntukkan bagi anak-anak Bumiputra antara lain Inlandsche School (Sekolah Bumiputra) kelas dua (Tweede Klasse), dengan lama sekolah lima tahun, Volksschool (Sekolah Desa) lama studi tiga tahun, serta sekolah lanjutan (Vervolgschool), yang merupakan lanjutan dari Sekolah Desa. Sekolah-sekolah tersebut berpengantar bahasa daerah. Untuk anak-anak yang berasal dari orang tua

${ }^{17}$ G.H. Von Faber, Oud Soerabaia: De geschiedenis van Indie's eerste koopstad van de oudste tijden tot de instelling van den gemeenteraad (1906), (Soerabaia: De Gemeente Soerabaia, 1931), hlm. 251

${ }^{18}$ Ibid.

19 Departemen Pendidikan dan Kebudayaan, Pendidikan di Indonesia dari Jaman ke Jaman, (Jakarta: Balai Pustaka, 1985), Bab IV 
yang memiliki kedudukan lebih baik, mereka bisa sekolah di Hollandsch Inlandschool (HIS) yang berpengantar bahasa Belanda. Ruslan Abdulgani, yang berasal dari Kampung Plampitan Surabaya merupakan salah satu anak kampung yang memiliki kesempatan sekolah di HIS.

Sekolah lain yang cukup terkenal di Kota Surabaya adalah Hoogere Burgerschool (HBS) dengan status sekolah menengah. Banyak tokoh penting di Kota Surabaya lulusan dari sekolah ini, antara lain Soekarno yang kelak menjadi Presiden Republik Indonesia. Sekolah ini didirikan tahun1875, menempati kawasan bekas kabupaten di sekitar Kebon Rojo. ${ }^{20}$ Pada awal abad ke-20, HBS Kota Surabaya merupakan salah satu sekolah terkemuka di Indonesia. Pada saat itu jumlah murid sebanyak 259 orang dan memiliki guru sebanyak 20 orang. ${ }^{21}$ HBS Kota Surabaya saat itu terkenal dengan sebutan Sekolah Radja. Pada tahun 1923, HBS Surabaya menempati gedung baru yang lebih luas di kawasan Ketabang, sebelah timur Balai Kota Surabaya. Dengan pemindahan lokasi sekolah tersebut di tempat yang lebih luas, maka jumlah murid pun bertambah banyak. ${ }^{22}$

Pada awal abad ke-20, hanya sedikit anak-anak di Kota Surabaya yang berkesempatan sekolah. Pada tahun 1920an, jumlah penduduk Kota Surabaya yang telah mengenyam pendidikan hanya sekitar tujuh persen. Dari jumlah anak-anak Bumiputra di Kota Surabaya yang berhasil mengenyam pendidikan Barat, sebagian dari mereka tinggal di kampung-kampung. Mereka adalah anak-anak dari orangorang yang cukup mampu, yang bisa membiayai mereka untuk sekolah. Melalui sekolah-sekolah yang mulai ada di Kota Surabaya, kesadaran berpolitik penduduk perkampungan di kota ini tumbuh. Pada awal abad ke-20, anak-anak kampung yang memiliki orang tua cukup mampu bisa mendapatkan kesempatan bersekolah. Sekolah telah menempa mereka menjadi pribadi-pribadi yang lebih terbuka dan menyadari sepenuhnya keadaan mereka sebagai orang yang terjajah.

Pada awal abad ke-20, mulai masuk gagasan-gagasan pergerakan nasional, yaitu gagasan untuk melawan penjajahan Belanda. Gagasan tersebut pada awalnya berkembang di Kota Batavia dengan Dokter Soetomo sebagai salah seorang pencentus yang berasal dari Surabaya. Dokter Soetomo yang pada tahun 1908 berstatus sebagai siswa sekolah dokter (STOVIA) di Batavia, bersama dengan Dokter

\footnotetext{
${ }^{20}$ Saat ini di kawasan tersebut berdiri Kantor Pos Besar Kota Surabaya yang terletak di Jalan Kabupaten.

${ }^{21}$ Krama Atmadja, Pendapatan Peperiksaan Adanja Kota Soerabaja, (Batavia: Landsdrukkerij, 1903).

${ }^{22}$ Jubileumboek HBS Soerabaia 1875-1975, (Den Haag: TP, 1975), hlm. 16.
} 
Wahidin Soedirohoesodo, memelopori berdirinya organisasi Budi Utomo. Soetomo ditunjuk sebagai ketua Budi Utomo yang pertama. ${ }^{23}$ Selanjutnya pada tahun 1911, berdiri perkumpulan Sarekat Islam (SI) di Solo yang dimotori oleh Samanhudi. Pendirian organisasi ini pada awalnya adalah karena persaingan dagang antara pedagang-pedagang Bumiputra muslim dengan pedagang Cina. Organisasi ini pada tahap berikut berkembang menjadi organisasi yang memiliki kesadaran besar untuk melawan penjajah Belanda. Sarekat Islam tumbuh menjadi organisasi yang kuat dan sangat besar ketika dipimpin oleh H.O.S. Cokroaminoto dan berkedudukan di Kota Surabaya.

H.O.S Cokroaminoto mulai memimpin SI sejak terpilih sebagai ketua organisasi ini dalam Kongres SI di Yogyakarta tahun 1914. Di bawah kepemimpinan H.O.S. Cokroaminoto, SI melesat bagaikan meteor dan meluas secara horizontal. Kota Surabaya sebagai basis SI berhasil tumbuh menjadi kota pergerakan, yang tidak saja menggerakkan kelompok-kelompok terdidik untuk secara sadar melawan penjajah Belanda, namun juga menggerakkan rakyat-rakyat kampung di kota ini untuk secara sadar memposisikan dirinya sebagai rakyat yang terjajah. Anggota SI meluas di kampung-kampung, mereka adalah para buruh pabrik, para petani penghuni tanah-anah partikelir, pegawai pemerintah Hindia Belanda, para pedagang, serta kelompok-kelompok profesi lain yang merasa tertindas oleh penjajahan Belanda.

SI yang secara ideologis memperjuangkan hak-hak rakyat kecil dengan cepat merebut simpati rakyat kampung di Kota Surabaya. Melalui organisasi yang dikelola secara modern inilah rakyat kampung memperoleh pelajaran penting tentang politik kebangsan. Rakyat kampung partikelir yang selama bertahun-tahun menjadi sapi perah para tuan tanah memperoleh kesadaran baru bahwa untuk keluar dari situasi yang menekan tersebut, mereka harus berjuang. SI merupakan salah satu media yang tepat untuk memperjuangkan nasib mereka. SI Surabaya berkembang menjadi organisasi yang sangat erat dengan perjuangan rakyat kampung partikelir dalam rangka memperbaiki nasib mereka. ${ }^{24}$ SI aktif mengorganisir para petani penghuni tanah partikelir, mendampingi mereka berhadapan dengan para tuan tanah yang sangat menghisap kehidupan mereka, serta mengusahakan penasehat hukum manakala para petani tersebut diajukan ke sidang pengadilan. Dengan cara semacam itu SI dianggap sebagai dewa penolong rakyat kampung yang sedang dilanda

\footnotetext{
${ }^{23}$ Marwati Djoened Poesponegoro dan Nugroho Totosusanto (ed.), Sejarah Nasional Indonesia: Zaman Kebangkitan Nasional dan Masa Hindia Belanda, (Jakarta: Balai Pustaka, 2010), hlm. 335. ${ }^{24}$ A.P.E. Korver, Sarekat Islam: Gerakan Ratu Adil?, (Jakarta: Grafiti Pers, 1985), hlm. 116.
} 
kesusahan. Dengan tempo yang relatif cepat SI berhasil menambah jumlah anggota secara signifikan. SI Cabang Surabaya di bawah kontrol Corkoaminoto tumbuh menjadi cabang terbesar di seluruh Hindia Belanda.

\section{Berdirinya Gemeente Surabaya dan Respon Rakyat Kampung}

Memasuki abad ke-20, perubahan besar terjadi di Hindia Belanda. Perubahan tersebut merupakan imbas dari kebijakan politik yang terjadi di negeri induk, yaitu Belanda. Pada periode itu, perhatian politisi di negeri Belanda terhadap kota-kota di Hindia Belanda mulai mengemuka. Hal tersebut merupakan imbas dari protes orang-orang Belanda yang tinggal di kota-kota di Hindia Belanda yang merasa tidak nyaman terhadap kondisi kota yang tidak terurus. Mereka menganggap bahwa pemerintah kolonial yang berkedudukan di Batavia kurang memperhatikan kondisi kota-kota, terutama kota yang jauh dari pusat kekuasaan. Sistem pemerintahan kolonial yang sangat birokratis tidak memungkinkan mereka untuk bertindak cepat menangani berbagai persoalan yang terjadi di daerah.

Beberapa tahun sebelum isu tentang kondisi perkotaan dijadikan tuntutan oleh orang-orang Belanda (nederlandsche burgerij) penghuni kota-kota di Hindia Belanda, di Belanda muncul tuntutan agar mereka diberi "hak bicara" (medezeggenschap) dalam proses-proses pembuatan kebijakan di bidang pemerintahan. Tuntutan tersebut menguat karena berbagai kebijakan yang dilahirkan oleh pemerintah juga akan berimbas pada keberadaan mereka di Hindia Belanda. Pada akhir tahun 1880, pada persidangan Tweede Kamer, salah seorang anggota bernama L.W.C. Keuchenius membuka perdebatan tentang perlunya di daerah-daerah di Hindia Belanda dibentuk suatu dewan yang disebut gewestelijk raden atau dewan daerah. Melalui lembaga tersebut, warga Eropa dapat berbicara menyuarakan asprasi. ${ }^{25}$

Inti dari tuntutan tersebut adalah bahwa daerah sudah semestinya diberi otoritas yang cukup besar untuk mengelola diri sendiri secara mandiri, tidak tergantung pada pemerintah pusat di Batavia. Dengan adanya hak untuk mengelola daerah, maka diharapkan daerah akan lebih mandiri dalam mengembangkan diri. Pembangunan bisa digenjot, sehingga problem-problem di daerah bisa diselesaikan dengan cepat. Salah satu problem di daerah, terutama di perkotaan, adalah buruknya lingkungan pemukiman untuk hunian rakyat Bumiputra. Pemukiman-

\footnotetext{
${ }^{25}$ Soetandyo Wignjosoebroto, Desentralisasi dalam Tata Pemerintahan Kolonial Hindia-Belanda: Kebijakan dan Upaya Sepanjang Babak Akhir Kekuasaan Kolonial di Indonesia (1900-1940), (Malang: Bayumedia, 2005), hlm. 4-5.
} 
pemukiman nyaris tidak diurus dengan baik, sehingga di banyak tempat berdiri rumah-rumah yang lebih mirip kandang binatang dibandingkan sebagai tempat tinggal manusia.

Perdebatan yang panjang di parlemen di Belanda menghasilkan sebuah keputusan, perlu dibentuk otonomi penuh di daerah-darah yang memenuhi syarat. Keputusan tersebut melahirkan undang-undang tentang otonomi daerah yang pertama di Hindia Belanda, yaitu Wet Houdende Decentralisatie van het Bestuur in Nederlandsch Indie, yang lebih dikenal dengan nama Decentralisatie Wet 1903.

Sebagai pelaksanaan dari Decentralisatie Wet 1903, maka pada tanggal 1 April 1906 disahkan pemerintahan Kota Surabaya yang otonom bernama Gemeente Surabaya. Berdirinya Gemeente Surabaya disahkan melalui Staatsblad No. 149 Tahun 1906. Dalam staatsblad tersebut dijelaskan bahwa dengan berdirinya Gemeente Surabaya, maka Surabaya ditetapkan sebagai kota otonom atau kota mandiri yang berkewajiban mengelola dan mendanai sendiri kota tersebut. Lebih lanjut diterangkan bahwa pemerintah pusat akan menyisihkan dana sebesar F 284.300 sebagai modal awal yang akan digunakan untuk menjalankan roda pemerintahan gemeente.

Sebagai konsekuensi atas pembentukan pemerintahan yang otonom, maka beberapa kewajiban yang sebelumnya dijalankan oleh pemerintah pusat dalam rangka mengelola Kota Surabaya, lebih lanjut akan diserahkan kepada gemeente. Beberapa kewajiban tersebut antara lain: perawatan, pembetulan, pembaharuan, dan pembuatan jalan umum, jalan raya, lapangan, pekarangan, taman dan tanamantanaman, parit, sumur, rambu-rambu jalan umum, papan nama, jembatan, dinding dam, penguatan dinding selokan dan got, pembandian umum, cuci dan kakus, pemotongan hewan, dan pasar; penyiraman jalan raya, pengambilan sampah di sepanjang jalan, pengambilan sampah di jalan-jalan kecil dan di lapangan; penerangan jalan; pemadam kebakaran; serta pembuatan makam.

Besaran dana yang diberikan oleh pemerintah pusat kepada Gemeente Surabaya tentu saja tidak cukup untuk menjalankan roda pemerintahan. Oleh karena itu, pemerintah pusat memberikan tugas kepada lembaga tersebut untuk mencari sumber pendapatan sendiri dengan cara menarik pajak kepada warga kota. Sumber pajak tersebut antara lain dari pasar, pemotongan hewan, pajak kendaraan, pajak keramaian, dan lain-lain.

Lahirnya Gemeente Surabaya yang diberi kewajiban untuk mengelola kota, berimbas kepada penghuni kota tersebut. Salah satu imbas yang sangat dirasakan oleh warga adalah tindakan Gemeente Surabaya untuk memberlakukan berbagai 
macam pajak baru yang harus dibayarkan oleh warga. Pajak baru tersebut antara lain bea pasar bagi para pedagang yang berjualan di pasar yang dikelola oleh gemeente, pajak sepeda, pajak binatang, pajak penyelenggaraan keramaian termasuk keramaian yang diselenggerakan secara individual (mantenan, sunatan), pajak pemotongan hewan, dan lain-lain.

Kewajiban membayar pajak yang bermacam-macam tersebut tentu saja membuat sengsara orang-orang yang tinggal di perkampungan. Sebagian rakyat Kota Surabaya yang tinggal di kampung-kampung adalah rakyat miskin, yang tentu saja merasa berat jika harus membayar pajak yang bermacam-macam jenisnya. Kondisi tersebut menyebabkan rakyat kampung mencurigai keberadaan gemeente yang baru saja lahir. Mereka menuduh gemeente sebagai lembaga baru bentukan pemerintah kolonial yang akan mencekik leher rakyat kampung. Dengan olok-olok mereka memelesetkan gemeente menjadi gua minta, yang diartikan sebagai lobang tanpa dasar yang terus-menerus meminta sesuatu kepada rakyat tanpa mau berhenti. ${ }^{26}$

Salah satu surat kabar yang terbit di Kota Surabaya pada tahun 1920an, Proletar, yang memiliki semboyan Organ dari Kaoem Proletar di Seloeroeh Doenia, selalu mengkritik Gemeente Surabaya dengan sangat pedas. Surat kabar tersebut sering memuat surat-surat pembaca dari warga perkampungan di Kota Surabaya tanpa disensor. Tulisan-tulisan mereka sangat khas, yang mencerminkan karakter rakyat Kota Surabaya yang lugas, keras, dan tanpa kompromi. Pada tanggal 1 Mei 1925 misalnya, Proletar memuat satu tulisan yang mengkritik tindakan Gemeente Surabaya yang memberlakukan tarif yang relatif mahal untuk penyembelihan hewan di rumah pemotongan hewan (abatoir) yang dikelola oleh gemeente. Secara lengkap tulisan tersebut adalah sebagai berikut:

"Orang semoea djoega tahoe jang goeminta ada mempoenjai roemah pemotongan (boekan
rumah jang motong orang) tapi boeat potong leher sapi, babi, dan kambing. Boeat kota
Soerabaja jang besar ini dimana orangnya ampir semoea boekan theosof djadi ia soeka makan
daging, maka tiap2 hari rata2 djumlah sapi jang dipotong ada seratoes, babi seratoes, dan
kambingd juga seratoes. La, ini semoea goeminta minta boeat satoe leher sapi f 7.10. boeat
seekor babi minta 4.05 dan boeat satoe kambing minta f 0.15 , Wadah, rojalnja, dalam satoe
tahoen sadja goeminta soedah bisa ing ing ke negeri Belanda. Abang goeminta tidak puas
minta potong goeroeng jang begitoe tinggi, tetapi dia mempoenjai akal lagi boeat
mengeloearkan wang. ah, selamanja dia cari-cari sadja akal boeat mengeloearken wang wang

26 William H. Frederick, Pandangan dan Gejolak: Masyarakat Kota dan Lahirnya Revolusi Indonesia (Surabaya 1926-1946), (Jakarta: Gramedia, 1989), hlm. 13. 
wang...teroes wang sampai dia djoega hamatanen wang. Pendek engkoh mindering nommer besar dah, dia!"27

Kutipan di atas merupakan bentuk kritikan yang amat pedas dari warga kampung kepada Gemeente Surabaya. Menurut si penulis, tarif-tarif penyembelihan hewan merupakan bentuk ekploitasi terhadap warga kampung yang akan membuat pemerintah kolonial, dalam hal ini Gemeente Surabaya, menjadi kaya raya. Hal tersebut bisa dibaca dari kalimat... Wadah, rojalnja, dalam satoe tahoen sadja goeminta soedah bisa ing ing ke negeri Belanda. Kalimat tersebut menggambarkan bahwa penarikan ongkos pemotongan hewan akan membuat gemeente kaya raya, karena menurut pandangan si penulis, dalam satu tahun tarikan sudah bisa dijadikan ongkos jalan-jalan ke negeri Belanda.

Namun, mahalnya ongkos penyembelihan hewan ternyata tidak diikuti dengan tindakan gemeente untuk mengelola rumah pemotongan hewan dengan baik. Dalam berita yang lain, yang juga dimuat di Proletar, digambarkan bahwa rumah pemotongan hewan tidak dirawat dengan baik sehingga menimbulkan bau yang sangat tidak sedap dari darah hewan yang membusuk. Kondisi seperti tersebut salah satunya terjadi di rumah pemotongan hewan yang terdapat di Kapasan Sidodadi. Dengan sangat pedasnya surat kabar Proletar menyindir bahwa:

\footnotetext{
"Barangkali semoea pendoedoek di Soerabaja soedah pernah melewati Kapasan Sidodadi. Di sitoe ada berdiri seboeah roemah pemotongan binatang poenjana...goeminta. Orang jang tidak bindeng hidoengnja tentoe berbaoe......wadah, oodookloonjoo jang paling sedap ialah tjap goeminta Spoerabaja. Itu baoe asal dari darah2 boesoek dari pemotongan sapi, babi, dan kambing. Soedah tentoe djika orang2 yang beroemah berdekatan dengan itoe istana darah, saban hari akan ditraktir oleh goeminta dengan exstra divinia itu. Orang2 kampoeng Sidodadi dan Kapasan semuanja ada menjadi sehat badannja karena marika tiap2 hari berbaoe minjak haroem si wangi divinia itu" ${ }^{28}$
}

Kutipan di atas yang dimuat di Proletar mewakili perasaan rakyat kampung Kapasan Sidodadi, yang setiap hari harus berhadapan dengan bau busuk yang bersumber dari rumah pemotongan hewan yang dikelola oleh gemeente.

\footnotetext{
27 “Tjiamah Tjioeng!!!: Goeminta Maoe Kaja. Djagal Menjadi Pajah,” Proletar, 1 Mei 1925. 28 “Tjiamah Tjioeng!!!: Goeminta maoenja sehat, tetapio penjakit biar dekat," Proletar, 15 Mei 1925.
} 
Berbagai tulisan yang dimuat di Proletar, baik yang dikirim oleh rakyat kampung di Kota Surabaya maupun yang ditulis oleh redaksi surat kabar tersebut, sejatinya mewakili perasaan penduduk kota tersebut, terutama penduduk kampung. Sebagian besar tulisan-tulisan yang muncul merupakan kritik pedas terhadap kebijakan yang dibuat oleh gemeente, yang dengan kata lain, tulisan-tulisan tersebut merupakan respon negatif atas lahirnya Gemeente Surabaya. Mereka menganggap bahwa keberadaan gemeente justru lebih banyak merugikan rakyat kampung dibandingkan keuntungan.

Wajar jika rakyat kampung nyaris tidak atau belum mendapatkan keuntungan atas kelahiran pemerintahan otonom (gemeente) di Kota Surabaya, karena sasaran pembentukan gemeente memang masyarakat Eropa yang berdomisili di kota tersebut. Jika mengacu pada proses pembentukan Undang-Undang Desentralisasi Tahun 1903, yang menjadi dasar pembentukan Gemeente Surabaya, maka yang berkepentingan atas pembentukan gemeente adalah masyarakat Eropa, bukan masyarakat Bumiputra. Rakyat kampung justru merasa terbebani dengan kehadiran gemeente. Mereka merasakan bahwa sejak berdiri Gemeente Surabaya, hampir setiap kegiatan yang menyangkut urusan umum harus mengeluarkan biaya. Munculnya berbagai biaya tersebut merupakan konsekuensi diberlakukan otonomi kepada kota. Karena pemerintah pusat sudah melepaskan mereka, maka tidak bisa tidak gemeente harus menanggung penyelenggaraan pemerintahan kota.

Pasar merupakan salah satu sumber pendapatan strategis dari Gemeente Surabaya. Setiap pedagang yang berjualan di pasar dengan otomatis menjadi target pajak atau bea bagi gemeente. Tarikan pajak penjualan yang dikenakan kepada para pedagang sering kali dikeluhkan oleh mereka, karena dianggap sebagai beban baru yang mengurangi keuntungan. Bagi pedagang yang laku berjualan tentu saja tidak menjadi persoalan, namun bagi pedagang yang berjualan dan tidak laku, tentu saja memberatkan. Petugas pajak pasar tidak pernah mau peduli dengan nasib pedagang di pasar, apakah dagangan mereka laku atau tidak. Bagi petugas pajak, kewajiban mereka adalah menarik pajak, dan para pedagang harus membayar pajak. Penarikan pajak yang bersifat memaksa tentu saja sering diprotes para pedagang, karena dirasakan sangat memberatkan mereka. Apalagi, sebagian besar pedagang yang berjualan di pasar adalah para pedagang menengah ke bawah. Ketegasan para penarik pajak sering diprotes masyarakat, terutama para pedagang. Salah satu cara yang dilakukan oleh masyarakat yang merasa keberatan dengan para penarik pajak adalah menuliskan keluhan di surat kabar, sebagaimana dicontohkan dalam Proletar tanggal 20 Juni 1925. 
Proletar tanggal tersebut memuat berita kecil berjudul "Nasibnja Pendjoeal Pasar Pabean Soenggoeh Sangat Edan-edanan," yang menceritakan nasib seorang penjual tembakau yang harus terusir dari pasar Pabean karena tidak melapor kepada Inlander Pasar Chef, yang bertugas menarik pajak. Penjual tembakau tersebut kemudian pergi ke kantor pasar untuk melaporkan bahwa ia akan berjualan di pasar Pabean, namun permintaan tersebut ditolak oleh petugas pasar. ${ }^{29}$ Kondisi tersebut merupakan contoh kecil tentang pengelolaan pasar-pasar di Kota Surabaya yang telah menjadikan pasar sebagai salah satu sumber pendapatan Gemeente Surabaya. Karena pasar dijadikan sumber pendapatan, maka siapapun yang berjualan di pasar harus ditarik bea atau pajak, baik pedagang kuat maupun pedagang lemah. Model pembayaran pajak pun dibuat sedemikian rupa supaya pendapatan gemeente menjadi banyak. Besaran bervariatif tergantung besar kecil dan ramai tidaknya pasar. Pasar yang besar dan ramai seperti pasar Pabean tarif pajak bulanan adalah $\mathrm{f}$ 10, sedang jika membayar harian sebesar f 0,45 setiap hari. Apabila pembayaran telat, maka akan didenda. Hal tersebut tentu saja memberatkan bagi pedagang kecil. Protes-protes pun dilayangkan pada Gemeente Surabaya, salah satunya melalui surat kabar Proletar. Surat kabar tersebut sangat getol menyuarakan nasib rakyat kecil yang tinggal di perkampungan Kota Surabaya.

Pembentukan gemeente yang dimaksudkan sebagai lembaga yang secara mandiri bisa mengelola kota ternyata mendapat respon yang negatif dari rakyat kampung. Hal tersebut disebabkan karena gemeente merupakan lembaga yang jauh dari realitas rakyat kampung. Pembentukan gemeente memang tidak ada kaitan sama sekali dengan orang-orang yang tinggal di kampung, karena pembentukan lembaga tersebut merupakan usulan orang-orang Eropa yang tinggal di kota-kota di Indonesia, yang mendapat dukungan dari kaum progresif di negeri Belanda. Maka wajar jika rakyat kampung merespon secara negatif, apalagi hampir semua kebijakan yang dibuat oleh gemeente memang tidak menyentuh keberadaan orang-orang yang tinggal di perkampungan. Bahkan, orang-orang kampung menganggap bahwa keberadaan gemeente justru menyengsarakan mereka. Pandangan negatif tersebut terus berkembang di kampung-kampung di Kota Surabaya, sehingga ketika pada akhir 1930, pemerintah pusat bermaksud mengintegrasikan rakyat kampung ke dalam sistem perkotaan di bawah yuridiksi gemeente, sebagian besar dari mereka menolak. Dinamika penolakan penggabungan kampung ke dalam gemeente akan dijelaskan pada pembahasan selanjutnya.

29 “Nasibnja Pendjoeal Pasar Pabean Soenggoeh Sangat Edan-edanan,” Proletar, 20 Juni 1925. 


\section{Penggabungan Kampung ke Sistem Gemeente dan Respon Penghuni}

Setelah Gemeente Surabaya berdiri pada tahun 1906, di wilayah ini terjadi dualisme pemerintahan, yaitu gemeente yang dimaksudkan untuk memerintah golongan masyarakat Eropa, serta sistem pemerintahan tradisional kabupaten yang telah ada yang mengelola masyarakat Bumiputra. Jika gemeente dipimpin oleh burgemeester atau walikota, maka pemerintahan kabupaten dipimpin oleh bupati. Wilayah kekuasaan dua pemerintahan tersebut juga berbeda, jika gemeente memiliki wilayah yang sebagian besar dihuni oleh masyarakat Eropa dan membentuk pemerintahan tingkat bawah yang disebut wijk (dipimpin oleh wijk meester atau wijkhoofder), maka wilayah kabupaten sebagian besar adalah perkampungan dan desa-desa pinggiran kota yang dihuni oleh rakyat kampung dan membentuk pemerintahan tingkat bawah yang disebut desa atau kelurahan (dipimpin oleh lurah). Pemerintahan tradisional sering disebut sebagai inlandsch gemeenten atau komunitas Bumiputra. Pada waktu itu terdapat 26 wijk dan 29 desa, masing-masing dikepalai oleh wijkmeester atau wijkhoofder dan lurah. ${ }^{30}$ Wijkmester bertanggung jawab kepada burgemeester, sedangkan lurah bertanggung jawab kepada bupati.

Dualisme sistem pemerintahan kota telah menyulitkan gemeente untuk mengontrol seluruh wilayah kota. Banyak kawasan yang tidak layak dari segi estetis dan syarat kesehatan, tidak bisa diperbaiki oleh pihak gemeente karena wilayah tersebut secara administratif masuk dalam wilayah kampung dan desa yang berada di bawah kekuasaan bupati. Sementara itu, jarang ada upaya dari bupati untuk memperbaiki kondisi perkampungan di Kota Surabaya.

Karena tidak ingin terus-menerus terjadi dualisme kepemimpinan di wilayah Kota Surabaya, maka pada tahun 1930 pemerintah pusat berencana menyatukan semua wilayah di Kota Surabaya dalam satu otoritas, yaitu gemeeente. Pertimbangannya adalah karena hampir semua wilayah di Kota Surabaya sudah berubah menjadi kawasan perkotaan. Dengan penyatuan itu, maka semua wilayah kota akan berada dalam satu kendali yaitu oleh gemeente. Langkah tersebut diharapkan dapat memaksimalkan penanganan lingkungan yang kurang sehat.

Pada saat gagasan penyatuan pemerintah kota diluncurkan oleh pemerintah, gagasan tersebut langsung menjadi kontroversi. Gagasan itu menjadi bahan perdebatan yang berkepanjangan di Volksraad yang berkedudukan di Batavia.

\footnotetext{
${ }^{30}$ Pembagian wijk di Kota Surabaya didasarkan pada keputusan Residen Surabaya tanggal 27 April 1914 no. 2/24. Lihat Sjamsu Koesmen dan pangestu B.W., Buku Petundjuk Kota Besar Surabaja, (Surabaya: Djawatan Penerangan Kota Besar Surabaja, 1957), hlm. 114. Untuk pembagian desa lihat "Perobahan daerah Soerabaja-Ken," Soeara Asia, 23 April 1943.
} 
Perdebatan yang terjadi antara beberapa anggota Volksraad, antara lain Stokvis, Soeroso, Dwidjosewojo, T. Kerkkamp, T. van Helsdingen, T. Kies, serta wakil dari pemerintah, T. Fuchrer, berkisar pada masalah apakah kampung-kampung yang semula berada dalam penguasaan bupati tersebut sudah seharusnya dimasukan dalam pengurusan gemeente ataukah tetap dimasukkan ke dalam posisi semula. Perdebatan yang berkepanjangan di Volksraad ternyata tidak menghasilkan sebuah kesepakatan apapun. ${ }^{31}$

Rencana pemerintah untuk memasukan wilayah perkampungan ke dalam pengelolaan gemeente nampaknya sudah bulat. Terbukti tanpa memperhatikan perdebatan yang berkembang di Volksraad, pemerintah tetap akan merealisasikan gagasan tersebut. Pada akhir bulan Oktober 1930, Gubernur Jawa Timur menerima telegram dari Sekretaris Negara bahwa Gubernur Jenderal telah mengeluarkan besluit bernomor 21 yang dikeluarkan pada bulan Oktober 1930, dan sudah ditetapkan dalam ordonansi bahwa status kampung-kampung di Kota Surabaya dicabut dan pengelolaan diserahkan kepada Gemeente Surabaya. Ordonansi tersebut akan berlaku efektif mulai tanggal 1 Januari $1931 .{ }^{32}$

Rencana pemerintah untuk mengambil alih pengelolaan kampung, atau dalam istilah masyarakat Kota Surabaya akan menghapus kampung, mendapat reaksi yang hebat dari rakyat kampung. Mereka menganggap bahwa gemeente telah melakukan upaya yang licik untuk mengambil alih kampung-kampung tempat tinggal masyarakat Bumiputra. Swara Oemoem, surat kabar yang dikelola oleh rakyat Bumiputra dengan sinis menuliskan bahwa upaya "pengoperan kampung", istilah yang dibuat oleh mereka, merupakan upaya gemeente agar bisa memperlihatkan cara kerja (pamer) lembaga tersebut kepada rakyat Bumiputra. ${ }^{33}$

Masyarakat Bumiputra yang tinggal di kampung-kampung juga mencurigai, bahwa pengoperan kampung bermotif finansial yaitu berkenaan dengan penarikan pajak kepada penduduk Bumiputra, sebagaimana ditulis oleh Swara Oemoem:

\footnotetext{
"Soepaja pendoedoek kampoeng bisa njatakna penggawejane Goeminta enggone mbersihi kampoeng lan soepaja pendoedoek kampoeng bisa seneng atine, moela dalan-dalan kampoeng saiki diwenehi got lan seteroese pinggir got mau digawekna dalan nganggo aspal. Pengramoete Goeminta marang dalan kampoeng mau pancen bagoes, toer saiki pendoedoek doeroeng dikenekna iki lan iku. Moeng sik tak koewatiri, yen kabeh mau sak pakan mantjing,
}

\footnotetext{
31 “Kampoeng Arep Diilangi?" Swara Oemoem, 15 Oktober 1930.

32 "Kampoeng-kampoeng Diilangi," Swara Oemoem, 25 Oktober 1930.

33 “Kijamate Kampoeng," Swara Oemoem, 15 November 1930.
} 
yaiku sarana enggal setitik ndjoer minta itu dan ini, ndjur ana padjege terop. Sing bijasane gak ana bandjoer djeboes mak grigil lan mak gregel." 34

"Agar penduduk kampung bisa melihat apa yang telah dikerjakan oleh gemeente ketika membersihkan kampung, dan supaya penduduk kampung senang hatinya, maka jalan-jalan kampung diberi saluran air, dan kemudian jalan-jalan diaspal. Pemeliharaan gemeente terhadap jalan kampung tersebut memang bagus, dan sampai saat ini penduduk belum ditarik [iuran] ini dan itu. Namun saya khawatir, semua itu hanya sekejap saja, karena setelah itu [gemeente] kemudian meminta [pajak] ini dan itu, bahkan mendirikan terop nantinya juga terkena pajak. Yang semula tidak ada [pajak], tiba-tiba diada-adakan dan memberatkan."

Pajak menjadi sumber utama ketakutan warga kampung terhadap rencana pengambilalihan pengelolaan kampung. Hal ini menjadi pikiran tersendiri bagi sebagian besar warga kampung yang miskin. Mereka telah membayangkan bahwa hidup di bawah kekuasaan gemeente tentu saja akan membebani mereka karena gemeente akan menarik banyak pajak. Mereka bahkan membayangkan hal-hal yang sangat ekstrem berkaitan dengan pajak, seperti pajak penyelenggaraan acara hajatan penduduk kampung:

"Grigil iku terikane setitik merga ing terop moeng jagongan wae, dene yen gregel ya oenda oesoek mergane umpamane nek nganggo towak-towakan tarikane lewih gede karo yen moeng seteman tok..." 35

"Tarikan pajaknya sedikit jika di terop hanya duduk-duduk saja, tarikan pajak akan menjadi besar jika di terop juga diadakan [acara] minum minuman keras."

Penduduk kampung merasa bahwa pengambilalihan pengelolaan wilayah yang menjadi tempat tinggal mereka memang lebih bermotif ekonomi, dan hal inilah yang membuat mereka trauma. Kondisi mereka yang miskin dengan penghasilan pas-pasan atau tanpa penghasilan tetap, tentu saja sangat berat. Bagi sebagian masyarakat yang masih tinggal di tanah-tanah yang dikuasai oleh tuan tanah, yaitu di tanah-tanah partikelir, penarikan pajak membuat mereka semakin bertambah

\footnotetext{
${ }^{34}$ Ibid.

${ }^{35} \mathrm{Ibid}$.
} 
berat, karena selain harus membayar berbagai kewajiban kepada tuan tanah juga membayar pajak insidental kepada gemeente. ${ }^{36}$

Reaksi yang keras dari penduduk penghuni kampung menjadi bukti bahwa telah tumbuh kesadaran baru pada masyarakat kampung bahwa area mereka menjadi incaran dari kelompok lain, dalam hal ini gemeente. Secara sadar masyarakat kampung mulai memahami bahwa ruang mereka menjadi ruang yang diperebutkan, oleh karena itu mereka juga berusaha mempertahankannya. Pada titik yang paling krusial ini tumbuhlah kesadaran kolektif yang tinggi antar sesama penduduk kampung. Jika dalam kasus-kasus perebutan ruang antara individu atau antar kelompok kesadaran kolektif yang muncul berskala kecil, maka dalam kasus ini kesadaran kolegial mereka muncul dalam spektrum yang lebih luas. Mereka sadar bahwa yang dihadapi bukan lagi individu atau kelompok, melainkan kekuatan terstruktur yang mengatasnamakan diri sebagai lembaga yang memiliki otoritas paling sah dalam penyelenggaraan komunitas besar yang disebut komunitas kota. Kelompok yang mereka hadapi adalah Gemeente Surabaya, sebuah lembaga yang memiliki legitimasi paling kuat untuk mewakili kekuasaan negara.

Menghadapi tekanan yang demikian kuat dari pemerintah, penduduk kampung-kampung di Kota Surabaya kemudian bersatu membentuk sebuah organisasi yang diberi nama "Perasaan Pendoedoek Soerabaja." 37 Organisasi ini menjadi wadah dari penduduk kampung yang tidak setuju dengan rencana pengambilalihan pengelolaan kampung oleh gemeente. Setiap satu minggu sekali perwakilan-perwakilan dari berbagai kampung berkumpul untuk membahas masalah yang mereka hadapi. Agar posisi mereka lebih kuat, maka sejak awal bulan

\footnotetext{
36 Sebelum kampung-kampung secara resmi dikelola oleh gemeente, penduduk kampung sudah ditarik beberapa macam pajak, antara lain pajak tanah yang ditarik oleh lurah-lurah untuk disetorkan kepada pemerintah di atasnya. Penduduk yang tinggal di tanah-tanah partikelir sudah dibebani berbagai kewajiban yang harus dibayar kepada tuan tanah, salah satunya adalah kewajiban membayar sewa tanah yang mereka tinggali. Selain itu setiap mereka memanen hasil tanaman mereka harus membagi hasil panenan tersebut kepada tuan tanah. "Sambate Wong Tani Tanah Partikelir Karah Ketintang," Swara Oemoem, 23 April 1930. Lihat juga Peratoeran Baroe atas Tanah Particulier di Tanah Djawa Sebelah Koelon Tjimanoek (Staatsblad 1912 No. 422), (Batavia: Landsdrukkerij, 1913). Peraturan yg termuat dalam buku tersebut secara khusus diperuntukkan untuk tanah partikelir di sebelah barat sungai Cimanuk, tetapi secara umum berlaku juga untuk tanah partikelir di tempat lain. F. C. Hekmeijer, Onteigeningsordonnantie terugbrenging van particuliere landerijen op Java tot het staatsdomein, (Batavia: G. Kolff, 1923).

37 “Kijamate Kampoeng," Swara Oemoem, 2 Desember 1930.
} 
Desember 1930 organisasi tersebut menjalin komunikasi dengan Persatuan Bangsa Indonesia (PBI) yang dipimpin oleh Dr. Soetomo.

Pada tanggal 1 Desember 1930, PBI telah menerima surat-surat dari perwakilan kampung yang menghendaki agar dilakukan "begandring" (vergadering) $^{38}$ rakyat Kota Surabaya untuk membahas rencana pemerintah pusat yang akan segera mengambil alih pengelolaan kampung ke pihak Gemeente Surabaya. Pada tanggal yang sama tidak kurang dari lima surat yang masuk ke pengurus PBI yang menghendaki agar PBI segera mengadakan "begandring" untuk tujuan yang sama. Beberapa surat yang dikutip oleh harian Swara Oemoem bahkan terkesan sangat emosional yang mencerminkan kekhawatiran yang luar biasa dari penduduk kampung bahwa mereka akan kehilangan "tanah tumpah darah" yang selama ini menjadi area komunitas mereka yang dikelola secara mandiri. Salah satu surat mengatakan:

\begin{abstract}
"Bareng aku maca Sw O (Swara Oemoem: pen) No. 126 bab: "Kijamate Kampoeng" atiku bandjoer keranta-ranta. Sedoeloer-sedoeloer mbok menawa wis makloem yen wong ing kampoeng ikoe ana bae gawene. Moela yen kita saiki dak nggatekna kabaran iku, mesti besoek dina boeri kita dewe sing bakal ngrasakna (ngomel). Moela saka iku aku ndjaloek remboege sedoeloer-sedoeloer sing wis ngerti mengkono oega marang badan "Perasaan Pendoedoek Soerabaja" kang wis kaping-kaping nganakake rapat." 39
\end{abstract}

\begin{abstract}
"Setelah aku membaca (tulisan di) Sw O (Swara Oemoem: pen) No. 126 yang berjudul "Kiyamatnya Kampung" hatiku merasa sedih. Saudara-saudara tentu sudah memakluminya bahwa di kampung ada saja hal-hal yang perlu dikerjakan. Oleh karena itu jika saat ini kita tidak memperhatikan hal ini [pengambilalihan pengelolaan kampung: pen], pasti akan menyesal di kemudian hari. Oleh karena itu saat ini juga saya minta saudara-saudara untuk bermusyawarah, demikian pula kepada [organisasi] "Perasaan Pendoedoek Soerabaja" yang sudah berkali-kali mengadakan rapat [agar] bermusyawarah lagi."
\end{abstract}

\footnotetext{
38 Banyak istilah bahasa Belanda yang diucapkan salah oleh masyarakat Kota Surabaya waktu itu. Begandring diucapkan salah oleh masyarakat, kata itu berasal dari Belanda vergadering, artinya pertemuan atau rapat. Lihat S. Wojowasito, Kamus Umum Belanda Indonesia, (Jakarta: Ichtiar Baru-Van Hoeve, 1995), hlm. 722. Gemeente (pemerintah kota/kotamadya) diucapkan dengan guminta. Dalam konteks sosial-politik ucapan masyarakat lokal tersebut menunjukkan dinamisnya kondisi sosial dan politik sehingga orang-orang awam yang kurang terpelajar dan kurang memahami bahasa Belanda sebagai alat komunikasi ikut terlibat dalam dinamika politik lokal. Mereka adalah masyarakat Bumiputra penghuni kampung-kampung di Kota Surabaya.

39 “Kijamate Kampoeng," Swara Oemoem, 2 Desember 1930
} 
Kekhawatiran dan ketakutan penduduk kampung terhadap rencana pengambilalihan kampung oleh gemeente merupakan imbas dari rasa curiga yang sangat besar terhadap gemeente. Gemeente selama ini dipandang sebagai sebuah lembaga pengelola kota yang secara terbatas hanya mengurusi komunitas Eropa di Kota Surabaya. Lembaga ini merupakan lembaga yang mandiri yang oleh pemerintah pusat diberi otoritas dan otonomi untuk mengelola komunitas kota. Sebagai lembaga yang mandiri dan otonom gemeente diberi hak untuk mengelola keuangan sendiri serta diberi kepercayaan untuk menggali keuangan secara mandiri pula. Salah satu sumber keuangan yang amat penting bagi gemeente adalah pajak yang ditarik dari warga kota.

Perebutan otoritas pengelolaan kampung antara penghuni kampung dengan gemeente harus dilihat dalam konteks yang cukup luas, antara keinginan untuk menata lingkungan kota dan kepentingan untuk memperoleh sumber pendapatan kota yang cukup besar. Konteks yang pertama tidak bisa dijadikan alasan yang cukup strategis mengingat selama ini kampung merupakan sebuah area yang hampir tidak diperhatikan oleh gemeente sejak Gemeente Surabaya berdiri pada tahun 1906. Dengan demikian, maka konteks kedualah yang paling memungkinkan dijadikan pijakan untuk melihat alasan pengambilalihan tersebut. Sejak gemeente berdiri dan dinyatakan sebagai sebuah lembaga yang secara otonom harus mencari pendanaan untuk dirinya-sendiri, maka sejak saat itu pula kebutuhan akan anggaran menjadi hal yang substansial. Jika anggaran tersebut hanya dibebankan kepada komunitas Eropa, tentu saja amat berat. Pada tahun 1930 jumlah komunitas Eropa yang tinggal di Kota Surabaya hanya berjumlah 26.463 orang. ${ }^{40}$ Masyarakat kampung lebih melihat aspek pembiayaan kotalah yang dijadikan alasan utama pengoperan tersebut. Pandangan masyarakat kampung tersebut mengemuka pada begandring openbaar, rapat terbuka warga kampung yang diadakan pada tanggal 20 Desember 1930 oleh PBI.

Dalam pertemuan masyarakat kampung tersebut dapat dilihat pandanganpandangan penghuni kampung dalam menyikapi rencana pemerintah yang akan segera dijalankan di Kota Surabaya. Secara umum, pandangan yang mengemuka dalam "begandring" tersebut terbelah menjadi dua. Pertama adalah pandangan yang mewakili pemikiran bahwa pengambilalihan pengelolaan kampung-kampung adalah jalan terbaik menuju perbaikan kampung-kampung miskin tersebut.

\footnotetext{
${ }^{40}$ Departement van Landbouw, Nijverheid en Handel, Volkstelling 1930: voorloopige uitkomsten 1e gedeelte Java en Madoera, (Bataviacentrum: Landsdrukkerij, 1931), hlm. 74-75.
} 
Pandangan ini diwakili oleh anggota-anggota gemeenteraad perwakilan rakyat Bumiputra Kota Surabaya yang hadir dalam "begandring" tersebut. Pandangan ini didukung seorang tokoh terkemuka Kota Surabaya yaitu Dr. Soetomo. Kedua adalah pandangan yang menolak ide pengambilalihan pengelolaan kampung, yang mayoritas disuarakan oleh para penghuni kampung.

Mula-mula, Dr. Soetomo yang merupakan ketua PBI dan seorang tokoh yang amat disegani oleh masyarakat Bumiputra Kota Surabaya memberi pengarahan sambil memimpin pertemuan. Ia mengemukakan bahwa setiap tindakan baru yang semula asing bagi masyarakat biasanya akan mengagetkan. Dr. Soetomo menganalogikan apa yang sedang dilakukan oleh gemeente terhadap kampungkampung di Kota Surabaya dengan tindakan Raffles ketika melakukan berbagai perombakan di Indonesia. Apa yang dilakukan oleh Raffles mengagetkan banyak pihak karena ia memasukan hal-hal baru dengan tiba-tiba. ${ }^{41}$ Dr. Soetomo nampaknya ingin mengambil hati masyarakat kampung yang menolak tindakan pemerintah untuk memgambil alih pengelolaan kampung. Ia memposisikan diri sebagai perantara antara masyarakat kampung dengan pihak gemeente. Menurut pandangan Dr. Soetomo, pengambilalihan kampung bukanlah semata-mata persoalan bagaimana gemeente nantinya memperoleh pemasukan dalam bentuk pajak, tetapi yang lebih penting adalah agar kampung-kampung miskin yang selama ini tidak diperhatikan nantinya ada yang menangani, yaitu gemeente. Kampung yang teratur beserta penghuni yang sejahtera merupakan cita-cita Dr. Soetomo sejak ia menetap di Kota Surabaya. Bahkan ia rela mengundurkan diri dari keanggotaan Gemeenteraad Surabaya pada tahun 1925 juga demi perjuangan agar kampung-kampung miskin di Kota Surabaya ditangani dengan serius oleh gemeente. ${ }^{42}$

Apa yang disampaikan oleh Dr. Soetomo dalam "begandring" tersebut tidak diperhatikan dengan baik oleh perwakilan-perwakilan kampung yang hadir. Mereka

\footnotetext{
41 "Gemeente lan Kampoeng," Swara Oemoem, 27 Desember 1930.

42 Pada tahun 1924 Dr. Soetomo terpilih menjadi anggota Gemeenteraad Surabaya. Dalam persidangan awal tahun 1925 ia mengusulkan agar Gemeente Surabaya menyisihkan anggaran untuk perbaikan kampung-kampung miskin di kota tersebut. Namun usulan Dr. Soetomo tidak disetujui oleh gemeente, sehingga ia beserta tiga anggota dari golongan bumiputra mengundurkan diri sebagai bentuk protes. Beberapa saat setelah Dr. Soetomo mundur dari gemeenteraad, anggaran untuk perbaikan kampung turun sebesar f 100.000. Turunnya anggaran tersebut mendapat cemooh dari kelompok masyarakat Kota Surabaya terutama yang berafiliasi dengan komunis sebagaimana ditulis dalam surat kabar mereka, Proletar. “Tjiamah Tjioeng!!: Goemintah”, Proletar, 30 Mei 1925.
} 
tetap mencurigai bahwa tindakan mengambil alih pengelolaan kampung adalah penyerobotan atas dasar kesewenang-wenangan. Terdapat perbedaan pandangan antara Dr. Soetomo dengan perwakilan penduduk kampung yang hadir dalam begandring tersebut. Dr. Soetomo yang seorang dokter lebih menekankan aspek kesehatan dalam proses pengambilalihan pengelolaan kampung. Jika kampungkampung berada dalam kendali gemeente, maka kondisi lingkungan akan lebih diperhatikan dibandingkan jika kampung-kampung tersebut tetap mandiri di bawah kekuasaan bupati, karena bupati tidak pernah secara langsung memperhatikan kampung-kampung Bumiputra. Ia menekankan supaya rakyat mengikuti kemauan gemeente jika perubahan yang akan dilakukan terhadap kampung-kampung miskin cocok dengan kehendak rakyat. Berkali-kali ia menekankan bahwa masuknya gemeente ke dalam kehidupan rakyat Bumiputra bukan berarti pertanda kemunduran bagi mereka, justru kemajuanlah yang akan diperoleh oleh rakyat. ${ }^{43}$

Pendapat Dr. Soetomo tersebut didukung oleh anggota gemeenteraad Surabaya dari golongan Bumiputra lainnya, yaitu Rooslan Wongsokoesoemo, Lengkong, dan Soendjoto. Mereka menekankan bahwa jalan terbaik bagi para penghuni kampung adalah melepas pengelolaan kampung kepada gemeente. Mereka berpendapat bahwa jumlah kampung di Kota Surabaya yang mencapai 176 sangat sedikit yang sudah diperbaiki, dan kondisi tersebut tentu saja merugikan para penghuni kampungkampung yang belum diperbaiki. Menurut Lengkong, yang membayar pajak ke pemerintah bukan hanya warga kampung yang kampungnya sudah diperbaiki tetapi juga warga kampung lain yang kampungnya masih belum diperbaiki. Soendjoto dalam pengarahannya mengatakan bahwa selama ini penduduk kampung secara mandiri mengelola kampung sendiri, tetapi karena kondisi ekonomi para penghuni kampung yang rendah serta tidak adanya aturan yang jelas tentang pengembangan pemukiman, maka kondisi kampung justru semakin semrawut tidak beraturan. Lebih lanjut ia mengemukakan hal yang cukup berbeda dengan anggota gemeenteraad yang lain, yang intinya bahwa jika gemeente ingin memperbaiki kampung sebenarnya tidak harus dengan mengambil alih pengelolaan kampungkampung tersebut, karena pengambilalihan akan menimbulkan efek sosial yang cukup besar. Efek sosial tersebut adalah lengsernya para pejabat tradisional yang paling rendah yaitu lurah. Jika kampung-kampung diambilalih pengelolaannya oleh gemeente maka jabatan lurah akan dihapus dan diganti oleh wijkmeester. Pelengseran lurah dikhawatirkan akan menimbulkan instabilitas pada rakyat kampung karena

43 “Gemeente lan Kampoeng," Swara Oemoem, 27 Desember 1930. 
lurah pada umumnya merupakan jabatan tradisional yang mengakar. ${ }^{44}$ Ia tetap menekankan bahwa pengambilalihan pengelolaan kampung cukup penting agar rakyat bisa menerima kembali pajak yang telah diberikan kepada negara dalam bentuk fasilitas yang akan dibangun oleh gemeente jika kampung di bawah penguasaan lembaga tersebut.

Masyarakat kampung sendiri sadar betul bahwa upaya mereka untuk menghalangi pengambilalihan pengelolaan kampung adalah tindakan yang sia-sia. Hal ini disebabkan karena lembaga formal yang harus melindungi mereka, yaitu kabupaten, yang selama ini berkuasa atas kampung-kampung tersebut ternyata tidak melakukan tindakan apa-apa. Pada satu sisi, dualisme kekuasaan di Kota Surabaya yang secara definitif berlangsung sejak gemeente berdiri, secara tidak langsung merugikan warga kampung. Mereka membayar berbagai jenis pajak yang disetor kepada atasan mereka, namun mereka tidak mendapatkan imbalan yang sepadan. Kampung-kampung dibiarkan rusak dan tidak mendapat fasilitas apapun, kondisi warga juga dibiarkan miskin tanpa jalan keluar. Pada sisi yang lain, kekuasaan tradisional menciptakan suasana tenteram karena mereka merasa berada dalam lindungan bangsa sendiri yang sederajat, bukan oleh bangsa asing yang kadang-kadang tidak menciptakan komunikasi yang intensif. Kampung, bagi para penghuninya menciptakan romantisme akan hubungan yang intim antar warga dan dengan kepala-kepala mereka. Di dalam kampung, kepala kampung, lurah, dan bupati adalah "ayah" bagi warga kampung yang memerankan diri sebagai "anak". Oleh karena itu, pengambilalihan pengelolaan kampung oleh gemeente menimbulkan kegoncangan yang luar biasa. Berhadapan dengan kekuasaan gemeente, yang notabene adalah kekuasaan asing, akan menimbulkan jarak sosial dan politik yang amat jauh. Kesenjangan terjadi antara dua lembaga yang berada dalam kekuasaan etnik yang berbeda. Kondisi ekonomi warga yang rata-rata miskin dengan rumahrumah yang sangat tidak layak telah menciptakan jurang pemisah yang luar biasa, baik secara riil maupun secara simbolik.

Pada akhirnya penduduk kampung menyadari bahwa pengambilalihan kampung adalah sesuatu yang tidak bisa ditawar lagi karena hal tersebut merupakan kemauan pemerintah. Mereka kemudian hanya melakukan "tawar-menawar" dengan pihak-pihak yang berkuasa. Hal ini terungkap dengan jelas dalam "begandring" tersebut. Wakil dari kampung Kedungklinter misalnya menyatakan, bahwa jika masalah pengambilalihan kampung sudah tidak bisa ditawar lagi, yang

\footnotetext{
${ }^{44}$ Ibid.
} 
artinya dalam lima hari ke depan kampung-kampung di Kota Surabaya akan berada dalam kekuasaan gemeente, maka ada beberapa hal yang diminta oleh warga kampung, khususnya warga kampung Kedungklinter. Pertama, wijkmeester yang akan diangkat untuk menggantikan lurah hendaknya orang yang cakap, yang paham terhadap kondisi warga kampung yang sebagian besar masih miskin, dan paham mengenai urusan kampung. Paham artinya, mereka tahu budaya warga kampung setempat. Kedua, dengan pengambilalihan kampung-kampung oleh gemeente maka secara otomatis wilayah yang dikelola oleh gemeente menjadi semakin luas dan penduduknya semakin banyak. Oleh karena itu, maka keanggotaan Bumiputra di gemeenteraad hendaknya diperbanyak, dan pegawai-pegawai Bumiputra di gemeente juga diperbanyak. Ketiga, anggota-anggota gemeenteraad baik yang mewakili golongan Bumiputra maupun golongan bangsa lain hendaknya mau turun ke kampung-kampung untuk melihat secara langsung kondisi kampung di Surabaya yang sebenarnya. ${ }^{45}$

Secara umum hampir semua perwakilan kampung merasa keberatan jika kampung-kampung diambilalih pengelolaannya oleh gemeente. Bahkan salah seorang wakil kampung yang hadir, yaitu Pranoto mengusulkan agar kampung-kampung bersatu dan membentuk gemeente sendiri. Ia mengusulkan agar Soendjoto, yang pada waktu itu menjadi anggota Gemeenteraad Surabaya, mau menjadi burgemeester dari gemeente yang ia usulkan. Maskan, perwakilan dari kampung lain berharap, agar gemeente usulan dari Pranoto juga dilengkapi dengan raad cilik, yaitu raad yang beranggotakan perwakilan kampung-kampung yang fungsinya sama dengan gemeenteraad. ${ }^{46}$

45 “Gemeente lan Wong Kampoeng," Swara Oemoem, 29 Desember 1930. Begandring yang diadakan di gedung PBI pada tanggal 20 Desember 1930 memang begandring yang menyedot perhatian banyak perwakilan kampung di Kota Surabaya. Begandring ini dianggap amat penting karena menyangkut eksistensi kampung yang status administrasinya akan segera berpindah tangan. Pengoperan kampung memang amat mencemaskan rakyat karena dalam bayangan mereka penguasa baru, dalam hal ini gemeente, adalah sebuah lembaga yang akan terus-menerus meminta imbalan kepada rakyat atas apa yang akan mereka kerjakan di kampung. Orang kampung selalu memelesetkan gemeente dengan gua minta. Kecemasan tersebut misalnya diungkapkan oleh Kadroen yang mewakili salah satu kampung yang mencontohkan bahwa setelah kampung-kampung di kota Malang dioper ke tangan gemeente, penduduk yang tinggal di kampung-kampung tersebut merasa rugi. Dengan tegas ia mengemukakan bahwa hal tersebut hendaknya jangan terjadi di Kota Surabaya.

${ }^{46}$ Ibid. 
Berbagai usulan, saran, dan masukan yang diajukan oleh perwakilan kampung yang beraneka macam itu oleh anggota gemeenteraad yang hadir dianggap sebagai ekspresi yang wajar atas kekesalan masyarakat penghuni kampung di Kota Surabaya. Celetukan-celetukan yang muncul merupakan dinamika yang khas dari kultur masyarakat Kota Surabaya yang lugas dan apa adanya, yang kadang tidak masuk akal dalam konteks waktu itu. Bahkan, Lengkong yang merasa dirinya sebagai bukan orang Surabaya sampai harus memberi tekanan agar jangan sampai orang-orang kampung mencurigai dirinya sebagai orang yang berpihak kepada gemeente atau berpihak kepada masyarakat Eropa yang tinggal di Kota Surabaya. Pada akhir pertemuan Lengkong menegaskan bahwa walaupun ia adalah orang Minahasa tetapi jiwa dan raganya diperuntukkan bagi bangsa Indonesia. Beberapa kali ia menekankan agar masyarakat Surabaya jangan salah memilih perwakilan mereka untuk menjadi anggota gemeenteraad dan jangan percaya begitu saja kepada apa yang diomongkan calon-calon gementeraad ketika mereka berkampanye. Ia menekankan agar persoalan yang menimpa penduduk kampung hendaknya dipecahkan bersama dan dipercayakan juga kepada anggota gemeenteraad perwakilan Bumiputra. ${ }^{47}$

"Begandring" malam itu memang tidak menghasilkan keputusan yang pasti. Para anggota gemeenteraad hanya berjanji akan membawa aspirasi masyarakat ke gemeente. Bahkan Rooslan Wongsokoesoemo menyatakan bahwa ia cukup bingung dengan suasana yang berkembang dalam "begandring" tersebut. Ia merasa bahwa usulan dari penduduk kampung akan sulit direalisasikan karena keputusan pengambilalihan pengelolaan kampung adalah keputusan dari gubernur jendral yang akan segera diberlakukan dalam beberapa hari mendatang. Ia juga mengkhawatirkan akan terjadinya protes keras dari penduduk kampung mengenai hal tersebut. Para anggota gemeenteraad sadar bahwa persoalan yang sedang dihadapi terkait erat dengan kultur masyarakat agraris yang sudah menyatu sedemikian rupa dengan tanah tempat tinggal mereka. Jika persoalan yang sedang dihadapi oleh masyarakat tidak dihadapi dengan baik, maka bukan tidak mungkin akan meledak gerakan protes seperti yang terjadi pada awal abad ke-20 di Kota Surabaya. Mengingat hal tersebut, maka Rooslan Wongsokoesoemo, sebagaimana dikutip oleh Swara Oemoem, berkali-kali mengingatkan kepada masyarakat agar jika ada keberatan-keberatan berkaitan dengan kebijakan pemerintah maka hendaknya diserahkan kepada yang berwajib karena:

\footnotetext{
${ }^{47}$ Ibid.
} 
"PBI ora gawe sikap apa-apa lan moetoes soepaja lan keberatan-keberatan saka rakjat iku dipasrahake marang sing wadjib, autoriteiten apa dene pers kang bisa noedoehake kepentingan mau marang oemoem." 48

"PBI tidak bersikap apa-apa dan memutuskan supaya keberatan-keberatan dari rakyat diserahkan saja kepada pihak yang berwajib, [lembaga] yang memiliki otoritas dan pers yang bisa menunjukkan hal tersebut kepada [masyarakat] umum."

Berbagai upaya penduduk kampung untuk menghalangi pengambilalihan pengelolaan kampung ternyata tidak berhasil. Pemerintah kolonial Belanda, dalam hal ini gubernur jenderal, tetap bersikukuh bahwa satu-satunya cara untuk mengubah kondisi kampung-kampung yang tidak beraturan, kumuh, dan menjadi sumber ketidaknyamanan kota adalah dengan mengambil alih pengelolaan kampung dari kekuasaan Bumiputra kepada kekuasaan Eropa. Pada tanggal 1 Januari 1931, keluarlah Undang-undang Penghapusan Inlandsch-Gemeenten Surabaya yang dimuat dalam Staatsblad No. 373 Tahun 1931. ${ }^{49}$ Sejak penetapan itu maka seluruh wilayah Kota Surabaya berada dalam satu kendali, yaitu Gemeente Surabaya.

Hapusnya dualisme pemerintahan di Kota Surabaya telah menjadikan kekuasaan gemeente semakin kuat dengan wilayah yang semakin luas. Pada saat kekuasaan baru berjalan satu dekade, Jepang keburu menduduki Indonesia. Pemerintah kota yang dibentuk oleh Jepang yang menggantikan gemeente, memerintah dan mengontrol kota dengan corak yang sangat berbeda. Kondisi tersebut berjalan sampai Indonesia memproklamasikan kemerdekaan pada tahun 1945. Pada tahun 1950-an, perhatian pemerintah kota tertuju pada kondisi jalan-jalan di Kota Surabaya yang sebagian besar dikuasai oleh rakyat miskin. Tujuannya adalah mengembalikan jalan raya pada fungsi asli, yaitu sebagai infrastruktur transportasi.

\section{Penutup}

Kondisi politik di Kota Surabaya pada awal abad ke-20, memperlihatkan situasi yang sangat dinamis. Aktivitas politik pada waktu itu tidak hanya diikuti oleh elit setempat, namun diikuti pula oleh rakyat perkampungan. Pada waktu itu, kegiatan politik yang dilakukan oleh rakyat kampung adalah dalam rangka

\footnotetext{
${ }^{48}$ Ibid.

${ }^{49}$ Staatsblad No. 373 Tahun 1931. Walaupun undang-undang tersebut berlaku sejak tanggal 1 Januari 1931 namun pelaksanaannya baru efektif mulai tanggal 1 Februari 1931. Lihat “Volksmeting," Swara Oemoem, 4 Februari 1931.
} 
melawan berbagai kebijakan pemerintah kolonial yang dirasakan merugikan mereka. Pada awal abad ke-20, terjadi perubahan drastis di Kota Surabaya yang sebagian besar perubahan tersebut menyerempet kepentingan rakyat kecil yang tinggal di kampung-kampung di kota tersebut. Salah satu perubahan yang terjadi adalah pemberian otonomi penuh kepada Kota Surabaya dengan berdirinya Gemeente Surabaya pada tahun 1906.

Otonomi tersebut tidak diberikan kepada rakyat Bumiputera yang tinggal di Kota Surabaya, melainkan kepada orang-orang Eropa, khususnya kepada orangorang Belanda yang tinggal di kota tersebut. Pemberian otonomi penuh tersebut berimbas kepada kebutuhan keuangan yang bersifat mandiri, baik pengelolaan maupun sumber pendapatan. Karena sumber pendapatan keuangan Gemeente Surabaya terbatas, maka semua hal yang menyangkut kepentingan umum dijadikan sumber pendapatan. Padahal, kepentingan umum tersebut tidak melulu terkait dengan orang-orang Belanda, melainkan sebagian besar justru terkait dengan rakyat Bumiputera. Dengan demikian, maka rakyat Bumiputera dijadikan salah satu target pendapatan, sehingga kehidupan mereka yang sudah susah menjadi semakin susah karena adanya kebijakan tersebut. Menghadapi situasi yang menekan, maka mereka melakukan berbagai perlawanan. Dalam konteks perlawanan itulah, rakyat kampung di Kota Surabaya melakukan berbagai strategi dan taktik yang dapat dikategorikan sebagai tindakan berpolitik dalam rangka memperjuangkan kepentingan mereka.

Strategi dan taktik yang dilakukan oleh rakyat kampung bermacam-macam. Bagi rakyat kampung yang sudah mengenyam pendidikan, walaupun pendidikan rendahan, mereka melakukan berbagai protes terkait kebijakan pemerintah kolonial yang kurang menguntungkan bagi mereka, dengan cara menulis di surat kabar. Di Kota Surabaya terdapat surat kabar yang dikelola oleh masyarakat Bumiputra, berskala tidak terlalu besar, dan mau menampung berbagai keluh kesah rakyat kelas bawah. Kritik mereka yang tajam hampir setiap hari menghiasai surat kabar tersebut. Strategi lain adalah melakukan protes langsung kepada pemerintah dengan cara memanfaatkan organisasi politik yang telah ada. Salah satu organisasi politik yang kerap dimanfaatkan oleh rakyat kampung untuk menyuarakan aspirasi mereka adalah Sarekat Islam (SI) yang dipimpin oleh HOS Cokroaminoto. Pertemuanpertemuan resmi yang diadakan oleh anggota gemeenteraad, yang populer disebut begandring, juga dimanfaatkan oleh rakyat kampung untuk menyuarakan aspirasi mereka. 


\section{Daftar Pustaka}

\section{Surat Kabar:}

Harian Umum, 12 Juni 1958.

Harian Umum, 1 Juli 1958.

Java Post, 21 Mei 1958.

Java Post, 10 Juni 1958.

Java Post, 12 Juni 1958.

Java Post, 25 Juni 1958.

Java Post, 10 September 1955.

Perdamaian, 2 Mei 1955.

Perdamaian, 3 Mei 1955.

Perdamaian, 11 Mei 1955.

Perdamaian, 14 Mei 1955.

Perdamaian, 17 Mei 1955.

Perdamaian, 26 Mei 1955.

Perdamaian, 31 Mei 1955.

Perdamaian, 1 Oktober 1955.

Perdamaian, 3 Oktober 1955.

Perdamaian, 25 Oktober 1956.

Perdamaian, 31 Desember 1956.

Pewarta Soerabaia, 25 Januari 1957.

Pewarta Soerabaia, 26 Februari 1958.

Pewarta Soerabaia, 26 Maret 1958.

Proletar, 1 Mei 1925.

Proletar, 15 Mei 1925.

Proletar, 30 Mei 1925.

Proletar, 20 Juni 1925.

Soeara Asia, 23 April 1943.

Soeara Rakjat, 23 Mei 1957.

Soeara Rakjat, 24 Mei 1957.

Soeara Rakjat, 15 Juni 1957.

Soerabaja Post, 8 Mei 1956.

Soerabaja Post, 7 Mei 1956.

Soerabaja Post, 14 Mei 1956.

Soerabaja Post, 16 Mei 1956.

Soerabaja Post, 21 Mei 1958.

Soerabaja Post, 22 Mei 1956.

Soerabaja Post, 4 Juni 1958.

Soerabaja Post, 12 Juni 1958.

Soerabaja Post", 19 Juni 1956.

Soerabaja Post, 19 Juli 1957. 
Soerabaja Post, 27 Juli 1957.

Soerabaja Post, 10 Agustus 1957.

Swara Oemoem, 27 Desember 1930.

Swara Oemoem, 29 Desember 1930.

Swara Oemoem, 15 Oktober 1930.

Swara Oemoem, 25 Oktober 1930.

Swara Oemoem, 15 November 1930.

Swara Oemoem, 2 Desember 1930.

Swara Oemoem, 4 Februari 1931.

Swara Oemoem, 23 April 1930.

Terompet Masjarakat, 25 Maret 1963.

Terompet Masjarakat, 10 April 1963.

Terompet Masjarakat, 29 April 1953.

Terompet Masjarakat, 16 Mei 1953.

Terompet Masjarakat, 24 Juni 1958.

Terompet Masjarakat, 28 Nopember 1963.

Terompet Masjarakat, 14 Desember 1963.

Terompet Masjarakat, 16 Desember 1963.

Terompet Masjarakat, 17 Desember 1963.

Terompet Masjarakat, 18 Desember 1963.

Terompet Masjarakat, 19 Desember 1963.

Terompet Masjarakat, 20 Desember 1963.

\section{Buku}

Akhudiat. 2008. Masuk Kampung Keluar Kampung: Surabaya Kilas Balik. Surabaya Henk Publica.

Akira, Oki. 1988. "The Transformation of the Southeast Asian City: The Evolution of Surabaya As a Colonial City," dalam East Asian Cultural Studies, 27 (March).

Anonim. 1913. Peratoeran Baroe atas Tanah Particulier di Tanah Djawa Sebelah Koelon Tjimanoek (Staatsblad 1912 No. 422). Batavia: Landsdrukkerij.

Anonim. 1975. Jubileumboek HBS Soerabaia 1875-1975. Den Haag: TP.

Atmadja, Krama. 1903. Pendapatan Peperiksaan Adanja Kota Soerabaja. Batavia: Landsdrukkerij.

Aqsha, Darul. 2004. K.H. Mas Mansyur (1896-1946): Perjuangan dan Pemikiran. Jakarta: Erlangga.

Basundoro, Purnawan. 2008. "Gerakan Protes Rakyat Miskin Kota Surabaya pada awal Abad ke-20," dalam M. Nursam, Baskara T. Wardaya, dan Asvi Warman Adam (ed.), Sejarah yang Memihak: Mengenang Sartono Kartodirdjo. Yogyakarta: Ombak.

Basundoro, Purnawan. 2009. Dua Kota Tiga Zaman: Surabaya dan Malang sejak Kolonial sampai Kemerdekaan. Yogyakarta: Ombak. 
Basundoro, Purnawan. 2012. Pengantar Sejarah Kota. Yogyakarta: Ombak.

Basundoro, Purnawan. 2013. Merebut Ruang Kota: Aksi Rakyat Miskin Kota Surabaya 1900-1960an. Jakarta: Marjin Kiri.

Blackburn, Susan. 2011. Jakarta: Sejarah 400 Tahun. Jakarta: Masup.

Crouch, Harold. 1999. Militer dan Politik di Indonesia. Jakarta: Pustaka Sinar Harapan.

Departement van Landbouw, Nijverheid en Handel. 1931. Volkstelling 1930: voorloopige uitkomsten 1e gedeelte Java en Madoera. Bataviacentrum: Landsdrukkerij.

Departemen Pendidikan dan Kebudayaan. 1985. Pendidikan di Indonesia dari Jaman ke Jaman. Jakarta: Balai Pustaka.

Dick, Howard W. 2002. Surabaya City of Work: A Socioeconomic History, 1900-2000. Athen: Ohio University Press.

Evers, Hans-Dieter dan Rudiger Korff. 2002. Urbanisme di Asia Tenggara: Makna dan Kekuasaan dalam Ruang-ruang Sosial. Jakarta: Yayasan Obor Inonesia.

Frederick, William H. 1989. Pandangan dan Gejolak: Masyarakat Kota dan Lahirnya Revolusi Indonesia (Surabaya 1926-1946). Jakarta: Gramedia.

Hageman, J. 1859. "Aanteekeningen nopens de industrie, handel en nijverheid van Soerabaja." Tijdschrift voor nijverheid en landbouw in Nederlandsch Indie.

Hekmeijer, F.C. 1923. Onteigeningsordonnantie terugbrenging van particuliere landerijen op Java tot het staatsdomein. Batavia: G. Kolff.

Ingleson, John. 1986. In Search of Justice: Workers and Unions in Colonial Java, 19081926. Singapore: Oxford University Press.

Ingleson, John. 2004. Tangan dan Kaki Terikat: Dinamika Buruh, Sarekat Kerja dan Perkotaan Masa Kolonial. Jakarta: Komunitas Bambu.

Kal, H. Th. 1906. Mededeelingen over de hoofdplaats Soerabaja," dalam Tijdschrift voor het Binnenlandsch Bestuur, Een-en-dertigste deel. Batavia: G. Kolff \& Co.

Koesmen, Sjamsu dan Pangestu B.W. 1957. Buku Petundjuk Kota Besar Surabaja. Surabaya: Djawatan Penerangan Kota Besar Surabaja.

Kohl, Herbert. 1992. From Archetype to Zeitgeist: Powerful Ideas for Powerful Thinking. Boston: Litle, Brown Company.

Korver, A.P.E. 1985. Sarekat Islam: Gerakan Ratu Adil?. Jakarta: Grafiti Pers.

Poesponegoro, Marwati Djoened dan Nugroho Totosusanto (ed.). 2010. Sejarah Nasional Indonesia: Zaman Kebangkitan Nasional dan Masa Hindia Belanda. Jakarta: Balai Pustaka.

Ricklefs, M.C. 2008. Sejarah Indonesia Modern 1200-2004. Jakarta: Serambi.

Sanit, Arbi. 2000. Badai Revolusi: Sketsa Kekuatan Politik PKI di Jawa Tengah dan Jawa Timur. Yogyakarta: Pustaka Pelajar.

Santoso, Jo. 2006. (Menyiasati) Kota Tanpa Warga. Jakarta: Gramedia. 
Singh,Vishal. 1958. “The Political Situation in Indonesia". International Spatator, 8 Nopember 1958.

Sullivan, J. 1992. Local Government and Community in Java: An Urban Case Study. Singapore: Oxford University Press.

Soemardjan, Selo. 2009. Perubahan Sosial di Yogyakarta. Jakarta: Komunitas Bambu.

Von Faber, G.H. 1931. Oud Soerabaia: De geschiedenis van Indie's eerste koopstad van de oudste tijden tot de instelling van den gemeenteraad (1906). Soerabaia: De Gemeente Soerabaia.

Von Faber, G.H. 1936. Nieuw Soerabaia: De geschiedenis van Indie's voornaamste koopstad in de eerste kwarteeuw sedert hare instelling 1906-1931. Soerabaia: N.V. Boekhandel en Drukkerij.

Wignjosoebroto, Soetandyo. 2005. Desentralisasi dalam Tata Pemerintahan Kolonial Hindia-Belanda: Kebijakan dan Upaya Sepanjang Babak Akhir Kekuasaan Kolonial di Indonesia (1900-1940). Malang: Bayumedia. 